\title{
A LÍNGUA PORTUGUESA E A CIDADANIA
}

\author{
Paulo Coimbra Guedes
}

RESUMO: The construction of a Portuguese teaching program to promote citizenship needs a political decision to guide teachers and students towards a new relationship between the language they speak and the language they need to write. Learners are entitled to reading and writing for meaningful production, and to the command of expressive resources historically built in the Portuguese language, and that is the task of the Portuguese teacher. The guidelines for that goal are provided by the process of acquiring language and grasping reality has to do with Brazilian lliterature.

PALAVRAS-CHAVE: ensino de língua portuguesa, currículo oculto, cidadania, leitura, escrita, língua falada, língua escrita, dialeto, literatura brasileira, história, política.

O desafio maior de construir uma política didático-pedagógica para o ensino de Língua Portuguesa compatível com a Escola Cidadã é a superação pessoal que cada um dos envolvidos nessa construção tem de empreender ${ }^{1}$. Nenhum dos outros conteúdos processados na escola quanto a língua que falamos e nenhuma outra das habilidades nela desenvolvidas quanto ao uso que fazemos da língua que falamos estão tão intimamente vinculados à vida pessoal e social de cada um de nós, dentro da escola ou fora dela. Nosso aprendizado a respeito da adequada forma de interagir verbalmente é parte integrante do nosso processo pessoal de aquisição da linguagem, que é parte integrante de nossa construção pessoal como ser humano em interação com outros seres humanos. Desde muito cedo, percebemos que nem sempre as pessoas falam para transmitir informações e quase sempre falam para nos informar a respeito da posição que ocupam ou acham que ocupam. E é desse modo que aprendemos a falar para sermos ouvidos e respeitados: a habilidade de produzir efeitos sobre nossos interlocutores desenvolve-se como parte do processo de aquisição da linguagem ${ }^{2}$.

Isso quer dizer que, ao aprendermos a falar, vamos aprendendo também como devemos falar: o que se diz e o que não se diz, como se diz e como não se deve dizer, que formas são corretas e quais são incorretas, quais as bonitas e as feias, as limpas e as sujas, o que é certo e o que é errado, o que a língua é e o que a língua não é. Ficamos sabendo que certas pessoas falam direito - geralmente são as mais bonitas e bem vestidas - e que outras - quase sempre pobres falam errado -, que devemos corrigir nossos erros para que nossa fala se pareça com a daquelas pessoas a quem se dá mais atenção.

Quem ensina tudo isso? Qualquer um que tenha aprendido isso tudo, isto é, todo mundo, começando em casa (não se diz tem uma mulher aí na porta; a gente diz tem uma

Paulo Coimbra Guedes é professor do Instituto de Letras da UFRGS.

${ }^{1}$ Documento produzido como parte de uma assessoria desenvolvida dentro do Projeto de Extensão Elaboração de uma Política Didático-Pedagógica para o Ensino de Língua Portuguesa na Rede Municipal de Ensino de Porto Alegre como base para a construção de programas de Língua Portuguesa nas escolas municipais.

${ }^{2}$ Ver "Linguagem, poder e discriminação", de Maurizzio Gnerre, 1984, em Linguagem, escrita e poder, p. 5-24. 
senhora), passando pela casa dos parentes, pela vizinhança, pelo rádio, pela televisão (os comunicadores aproveitam com especial deleite as oportunidades em que podem chamar atenção para erros de Português cometidos por quem entrevistam, especialmente se forem lideranças populares), chegando até a escola, que muito pouco tem tido a esclarecer e muito a reforçar tais ensinamentos.

Desde a Direção, que ameaça punir - às vezes pune - quem escreveu palavrões nas paredes da escola, passando pelos professores - às vezes até mesmo os de Português - que deploram a qualidade da leitura e da escrita dos alunos sem nada terem feito a favor dessa qualidade, que cometem erros de ortografia nos quadros de suas salas de aula e reclamam da ortografia dos alunos, chegando à servente que repreende as alunas dizendo que moça não grita, que só vileira fala daquele jeito, ao vigia que exige que os alunos o chamem de senhor, todo mundo exercita o natural direito de dar o seu palpite educativo sobre a mais adequada conduta lingüística.

Nenhum dos outros conteúdos tratados na escola, enfim, é tão desgraçadamente interdisciplinar quanto Língua Portuguesa e nenhuma mais do que ela está tão nocivamente presente no currículo oculto da escola. Além disso, nenhuma outra é tradicionalmente orientada por uma política didático-pedagógica que se tenha tornado historicamente tão sem sentido e tão distante de sua finalidade original e que tenha sido desde sempre tão incompatível com a promoção da cidadania.

Por isso, construir uma política didático-pedagógica para o ensino de Língua Portuguesa compatível com a Escola Cidadã envolve bem mais gente do que apenas os professores de Português, mais do que a melhor das vontades, mais do que uma consciência histórica e do que as mais adequadas teorias lingüística e pedagógica: envolve, além disso tudo e mais, fundamentalmente, uma pessoal, íntima e intransferível tomada de posição política capaz de levar a uma nova relação com a linguagem, com a Língua Portuguesa, com o ensino de Língua Portuguesa, com a língua que falamos, com a língua que nossos alunos falam, com a língua em que eles e nós temos de escrever.

Essa nova relação a ser construída terá de nos encaminhar para a superação da visão colonizada que temos de nós mesmos, visão que o tradicional ensino de Português muito contribuiu para que construíssemos dentro de nós. Essa fundamental posição política a ser tomada é a proclamação, para nós mesmos, que nós, brasileiros, - ao contrário do que sempre as elites dirigentes afirmaram e fizeram a escola repetir e fazem os meios de comunicação de massa reiterar - somos tão capazes quanto os demais seres humanos do Planeta de dar conta de todas as nossas necessidades expressivas na língua que falamos (LUFT, 1985). E, como consequiência dessa proclamação de nossa pertinência ao gênero humano, consideramos que, se nós não falamos muito bem o português, não é por causa de uma incompetência de que só nós, brasileiros, seríamos portadores, mas pelo singelo motivo de que falamos uma outra língua, um pouco parecida com o português, que, até mesmo por ironia, a gente pode continuar chamando de português.

E por que essa tomada de posição é política? Porque, independentemente dos argumentos científicos que a sustentam, essa decisão proclama nosso direito à cidadania: apenas nessa condição de seres humanos dotados de plena habilidade de linguagem poderemos nos considerar capazes de expressar nosso direito aos "bens materiais necessários para a sustentação de nossa existência física, aos bens simbólicos necessários para a sustentação de nossa existência subjetiva e aos bens políticos necessários para a sustentação de nossa existência social", conforme a definição de cidadania que orientou a discussão dos Eixos Temáticos da Constituinte Escolar ${ }^{3}$.

Como conseqüência dessa tomada de posição, segue-se que vamos considerar que nossos alunos são tão brasileiros e seres humanos como nós e, também como nós, capazes de dar conta de suas necessidades expressivas na língua que falam. E, se o jeito como eles falam

\footnotetext{
${ }^{3}$ Ver p. 19, de "Princípios de Convivência", em Congresso constituinte; eixos temáticos: Cadernos Pedagógicos, 1995.
} 
parecer diferente do nosso jeito de falar, consideremos que falamos dialetos diferentes da língua que todos falamos no Brasil, pois que será a nossa decisão política (e não a decisão política das elites escondida sob o disfarce de uma filologia colonizada) que vai passar a orientar a delimitação e a caracterização de língua e dialetos no Brasil.

Proclamemos, a seguir, - agora que já decidimos que a língua portuguesa não vai mais nos assombrar - que vamos pô-la a nosso serviço, tirando todo o proveito de sua tradição de língua escrita inserida na cultura ocidental. Vamos declarar nosso todo o patrimônio cultural construído nessa língua escrita, considerando que é legítimo direito do povo brasileiro não apenas ter acesso a ele, mas também estabelecer uma relação pessoal com os textos historicamente considerados significativos nessa língua, avaliando-os pelo sentido que fizerem para a nossa vida. Passemos a considerar que nossa tarefa de professores de Português é ensinar nossos alunos a ler (e a nós mesmos também, a partir dessa atitude que acabamos de adotar) não mais para acatar os sentidos já construídos para esses textos nessa tradição, mas para produzir nossa própria leitura deles, enriquecendo nossas vivências com as vivências neles construídas.

Com a mesma finalidade, vamos nos apropriar também da língua escrita, lançando mão dos recursos expressivos nela historicamente construídos para contarmos a nossa história, darmos nossos testemunhos e depoimentos, construirmos nossas opiniões, expormos nossos argumentos, expressarmos a música da língua que falamos. Vamos trabalhar sobre essa língua, enriquecendo-a com as contribuições de nossa fala para que ela se torne mais capaz de expressar tudo isso e o mais que tivermos a registrar nela do jeito que nos parecer mais adequado e belo de deixar por escrito ${ }^{4}$.

Libertemo-nos, libertemos nossos alunos e nossas aulas da pesada herança colonialista que tem feito do ensino de Língua Portuguesa um dos mais eficazes instrumentos de exclusão do povo brasileiro, não só da escola, mas também da vida cultural e política do País. Substituamos o silenciamento a que costumam ser submetidos os alunos, que não falam a língua em que estão escritos os livros e que não dominam a língua em que deveriam escrever, pela escuta atenta do que eles têm a dizer a respeito deles mesmos e a respeito da realidade social e cultural em que vivem. Substituamos a estigmatização de sua fala pelo incentivo à leitura e ao exercício da escrita para que eles estabeleçam com a língua dos livros uma relação de domínio e não de temor ou de adesão aos valores nela expressos. Transformemos cada aula de Língua Portuguesa não só numa atividade de exercício da cidadania mas principalmente em experiências de vida democrática, de participação social, de tomada da palavra, de construção de um conhecimento civilizador a respeito da experiência compartilhada pela comunidade.

\section{1 - A TRADICIONAL POLÍTICA DIDÁTICO-PEDAGÓGICA DO ENSINO DE PORTUGUÊS}

Por que nenhuma outra disciplina é tradicionalmente orientada por uma política didático-pedagógica que se tenha tornado historicamente tão sem sentido e tão distante de sua finalidade original e que tenha sido desde sempre tão incompatível com a promoção da cidadania? O ensino tradicional de Língua Portuguesa teve uma vez a finalidade de treinar os alunos para lerem e apropriarem-se das interpretações tradicionais dos autores clássicos da língua e para expressarem-se oralmente e por escrito segundo os modelos de discursos e textos forjados numa língua culta construída a partir dos textos desses autores. Para que deveriam aprender a fazer isso? Para se legitimarem no exercício do poder e da administração, que, como

\footnotetext{
${ }^{4}$ Ver, a respeito da construção dos recursos expressivos da língua, pelo trabalho sobre ela exercido historicamente pelos seus falantes, Discurso, estilo e subjetividade, de Sírio Possenti, 1988, especialmente o capítulo 4, "Língua e Discurso", p. 47-64.
} 
até hoje ainda podemos ler em colunas de jornalistas alinhados com o sistema, só podem ser exercidos por quem fala corretamente o português ${ }^{5}$.

Se nem sempre esse ensino tradicional foi capaz de dar conta dessa tarefa, certamente sempre foi e continua sendo muito eficiente na desqualificação da língua falada pelo povo brasileiro e na exclusão da escola da grande maioria dos alunos que falam essa língua ${ }^{6}$. Mais sucesso ainda tem tido na inculcação da incompetência para o exercício da escrita na maior parte dos que se submetem a nela permanecer apesar daquele desalentador diagnóstico a respeito de sua capacidade comunicativa na língua em que deveriam ter aprendido a expressarem-se.

Esse ensino tradicional, baseado numa teoria da linguagem que a vê como a expressão do pensamento lógico, acabou por se reduzir ao ensino cada vez mais diluído dos nomes que a gramática tradicional usa para designar os dados da língua que selecionou para examinar ${ }^{7}$. Enquanto trabalhava, até os anos cinqüenta, apenas com alunos que tinham algum acesso em casa ao dialeto culto, o ensino tradicional fez algum sentido, mas, depois que a democratização apenas quantitativa da escola trouxe para dentro dela quem não tinha acesso a essa língua, sujeito, predicado, complemento nominal, etc. perderam qualquer contato com a realidade da língua falada e ouvida por esses alunos.

Perderam, na verdade, contato com a língua falada pelo professor de Português, que já percebeu que não faz mais sentido aquele velho papel - implícito no ensino tradicional de Língua Portuguesa - de guardião da língua culta dos poderosos contra a invasão dos bárbaros (com esta palavra os gregos designavam os que não sabiam falar, isto é, os que não sabiam falar grego). Assumindo-se, desde os anos setenta, como trabalhador que se organiza para reivindicar salário e condições de trabalho, o professor vem construindo uma identidade política que o coloca contra os poderosos, entre os bárbaros, entre aquela considerável parcela do povo brasileiro que se organizou em movimentos, sindicatos, associações, partidos para lutar pela qualificação de sua existência. Tais embates deixaram bem claro que a língua culta das elites já não conseguia mais desempenhar a tarefa de identificar aqueles que estavam naturalmente destinados a mandar e que um novo discurso passava a fazer parte da cena política brasileira: o discurso operário, o discurso sem-terra, o discurso funcionário público, o discurso professor, expressando as reivindicações desses bárbaros na língua que o povo brasileiro construiu para expressá-las, desistindo de esperar por uma escola - historicamente sonegada pelas elites dirigentes - que lhes ensinaria a correta maneira de fazê-lo em bom vernáculo.

Ensinaria? Não, não ensinaria. O projeto educacional das elites foi muito bem sucedido em seu desígnio de manter ignorante o povo brasileiro (RIBEIRO, 1979, p.11-23), e o ensino tradicional de Português não ensinou a língua culta ao povo porque a língua culta não deveria ser ensinada ao povo, mas resguardada como propriedade privada de alguns poucos encarregados de usar esse saber para aterrorizar os que nunca deveriam ter acesso a ela. Se o projeto fosse ensiná-la, não teriam faltado - além das escolas, das boas condições de trabalho para os professores e das demais condições materiais que sempre faltaram - livros para ler, dicionários para consultar, vocabulários ortográficos e gramáticas para aprender. $\mathrm{O}$ Vocabulário Ortográfico da Língua Portuguesa, editado pela Academia Brasileira de Letras em cumprimento à lei que alterou a ortografia em 1973, está esgotado há mais de dez anos; fosse mesmo para ser a ortografia posta ao alcance do povo, cada escola no Brasil teria recebido um exemplar para a biblioteca que teria.

\footnotetext{
${ }^{5}$ Ver a propósito do terrorismo cultural, promovido pela grande imprensa sobre as manifestações da cultura popular a entrevista de Alfredo Bosi ao jornal Brasil Agora, n. 35, v. 2.

${ }^{6}$ Ver o artigo de Miriam Lemle "A variação na forma fonológica", que, apesar deste título técnico, trata das repercussões políticopedagógicas do ponto de vista com que costumam ser considerados no Brasil os dialetos falados pelas classes populares. Este artigo foi publicado no Boletim da Associação Brasileira de Lingüística, 1983, p. 22-29.

${ }^{7}$ Ver o livro - fundamental para o estabelecimento de uma nova visão a respeito do que possa vir a ser ensinar Português - Portos de Passagem, de João Wanderley Geraldi, 1991.
} 
À semelhança dos orçamentos públicos, também a língua culta foi historicamente privatizada, e esse dado cultural inerente ao tratamento que as elites sempre deram aos bens públicos faz-nos compreender porque o critério de aferição do domínio da língua culta e da habilidade de escrever corretamente se manteve permanentemente impreciso e obscuro e porque toda a preocupação com a linguagem correta não serviu para estabelecer um consenso sobre o bem escrever que se tivesse tornado escolarmente disponível para ser tomado como a língua correta, nem se traduziu num consenso implementado por alguma instituição normatizadora da língua oficial a exemplo das academias espanhola e francesa. Na falta desse consenso e dessa autoridade, ninguém ficou habilitado a declarar-se conhecedor da verdadeira norma culta brasileira, pois qualquer certeza sobre ela é constantemente submetida a eventuais pareceres de alguma autoridade de plantão e pode ser, a qualquer momento, abalada por uma interpretação divergente da que a originou.

E essa atitude diante da língua faz parte do nosso cotidiano: todo professor de Português já passou pela situação de ser apontado como alguém perto do qual todos os demais deviam tomar cuidado com sua linguagem, e muitos já passaram pela experiência de serem repreendidos - às vezes por aquela mesma pessoa - por falarem como todo mundo e não como professores de Português. Ou seja, os donos da língua sequer têm existência concreta, pois a língua deve ter segredos que escapem a todos.

O ensino tradicional de Português, que só ouve a língua falada pelo aluno para exemplificar erros de português, que faz um discurso sobre a gramática, que apresenta os bons autores da língua como modelos inatingíveis, nunca pretendeu ensinar a língua culta, mas apenas apresentá-la ao aluno de uma forma suficientemente difusa para que ele ache mais prudente calar-se sempre que pressinta estar diante de uma de suas manifestações. Por causa disso, ninguém se sente responsável pela ortografia, pela acentuação, pela preservação das formas de uma língua culta que nem expressa uma unidade nacional nem se apresenta como um bem público, disponível para a expressão de nossa identidade brasileira. Por causa disso, aprender Português nunca foi nem um direito nem um dever de cidadão: sempre foi uma deliberação pessoal para satisfazer interesses privados.

Igualmente privatizante tem sido o tratamento dado ao texto na aula de Português, a começar pelo velho hábito de ler para a turma o melhor texto da aula, consagrando-o como melhor apenas por esse ritual. Não há discussão de critérios, não há comparações entre textos; dá-se sumariamente a entronização do artista pelo reconhecimento de seu dom. O trabalho dos outros alunos para produzir o seu texto perde toda a importância diante dessa revelação. A alegação de que só se lêem os bons textos para não envergonhar os que não sabem escrever que deveriam ali estar para aprender, mas parece que já deveriam ter aprendido - só serve para eximir o professor de ensiná-los. Do mesmo modo, o mais recente hábito de fazer o aluno desabafar por escrito, expor os seus problemas numa correspondência privada com o professor colocando-o numa posição de psicólogo que compreende, desloca a relação professor - aluno para um terreno que o professor não está profissionalmente preparado para pisar.

\section{2 - ENSINAR PORTUGUÊS É DESPRIVATIZAR A LÍNGUA ESCRITA}

O pedagógico, diferentemente do psicológico, está no âmbito do público: se escrever tem, de fato, um valor terapêutico, não é por isso que o professor de Português vai incentivar seu aluno a escrever um diário, cartas, bilhetes, desabafos; pode fazê-lo para que o seu exercício desses textos privados aprimorem o seu artesanato da escrita. Não é com textos privados, no entanto, que vai ser encaminhado o trabalho em sala de aula, mas com textos produzidos para a escola no sentido estrito, para a instância pública da sala de aula, para serem dados a uma leitura pública, avaliados segundo critérios de conhecimento público, analisados e 
discutidos com a finalidade de melhorar-lhes a qualidade e expandir os recursos expressivos de seu autor.

Mas estaria o professor de Português preparado para tratar a língua escrita como um bem público e para dar um tratamento público ao texto de seus alunos? Mais ainda: estaria o professor de Português preparado para estabelecer com a língua dos livros uma relação de domínio e não de temor ou de adesão aos valores nela expressos? Todos sabemos que não, que não foi isso que lhes ensinou o curso de Letras. Pelo contrário, o que mais fez o curso de Letras foi implantar definitivamente em seu coração o terror paralisante imposto pela pretensa necessidade de escrever apenas se tivermos certeza de que o faremos na língua correta. Ninguém se sente mais aterrorizado pela intangível língua das elites do que o professor de Português, que quase sempre prefere não errar a escrever e concordar com a gramática a seguir sua intuição lingüística.

Também esse terror e essa falta de preparo precisam ser enfrentados no grito: decretemos que vamos aprender a escrever enquanto ensinamos nossos alunos a escrever e que esse aprendizado será o nosso mestre. Nossa prática da escrita é que vai nos proporcionar o indispensável domínio dos recursos expressivos da língua para avaliar em nosso texto e no texto de nossos alunos as dificuldades de organizar por escrito o conhecimento que precisamos construir sobre nós mesmos para nos livrarmos da imagem que a língua dos poderosos forjou a nosso respeito. Tomemos como guia para o nossa tarefa pedagógica o trabalho realizado pela literatura brasileira, que, já nas suas primeiras manifestações, logo depois da Independência, ao atribuir-se a tarefa de desvendar o Brasil, colocou-se o problema de tornar a língua portuguesa, criada por um outro povo para expressar uma outra paisagem e uma outra sociedade, adequada para também expressar a paisagem e a sociedade que os poemas, contos, romances, ensaios brasileiros iam descobrindo e desvelando para os brasileiros.

A língua portuguesa em que escreveu a literatura brasileira nunca foi a língua portuguesa escrita pelas elites colonizadas, pelos guardiães da norma culta lusitana, que sempre nos viram (não há quem continue vendo?) como um prolongamento degradado da cultura ocidental em que fomos inseridos pelo Descobrimento. A crítica a essas elites também sempre fez parte tanto da temática quanto da língua em que se expressou a literatura brasileira, que sempre propôs àquela tradição um diálogo insubmisso e construtivo e expressou para seus leitores brasileiros uma proposta de construção de uma auto-estima nacional à revelia dos projetos daquela elite.

Esqueçamos a colonizada língua culta das elites e dediquemo-nos à desprivatização da língua escrita. Apropriemo-nos - professores e alunos - da tradição construída na língua escrita por portugueses e brasileiros antigos e modernos e contemporâneos com o direito que acabamos de proclamar que temos sobre essa língua. Transformemos em tarefa sistemática de sala de aula o trabalho que vem sendo executado pela literatura brasileira para que escrever na escola passe a ter mesma serventia que tem tido na nossa vida cultural,. Tratemos de construir uma pedagogia da língua em que se escreve no Brasil: ensinemos nossos alunos a ler e a escrever não para aderirem à língua culta, não para renegarem o seu dialeto de origem adotando a forma de falar e pensar das elites, mas para dominarem a língua escrita, usando-a como um instrumento para organizar nosso entendimento pessoal sobre nossa relação conosco mesmos, com a linguagem, com a realidade social em que vivemos, com a língua em que escrevemos, para, enfim, construir nossa identidade. .

No momento em que com ele se encontra o professor de Português, o aluno já desenvolveu com a língua, com a escrita e com a leitura uma relação orientada pela mentalidade colonizada, que já se encarregou de fazê-lo sentir-se um ser desqualificado para o discurso, incapaz de pensar, dizer e escrever qualquer coisa que não seja o que a escola lhe apresentou como o que se deve pensar e dizer. Essa desqualificação é que o professor de Português tem de tomar como ponto de partida para o seu trabalho de construção de leitores e escritores. Para saber de que modo e em que grau a relação de seus alunos com a língua culta 
foi afetada por ela e, a partir daí, construir uma estratégia para transformá-la em uma relação orientada pela construção da cidadania, o professor precisa ouvir seu aluno falar e ler o que ele escreve $^{8}$.

A construção da cidadania começa, portanto, no respeito e na atenção com que o professor ouve o que o aluno tem a dizer no dialeto em que ele é capaz de dizê-lo. Cabe ao professor a iniciativa de fazer o aluno falar, não para reproduzir o discurso que a escola lhe apresenta como o discurso a ser repetido na escola, mas para falar dele mesmo e de sua realidade social mais próxima. Invertendo a direção em que se costuma dar esse diálogo, cabe ao professor o esforço para entender o sentido e o valor dos recursos expressivos que compõem o dialeto que o aluno fala, balizar as diferenças que o distinguem do dialeto em que se expressa o professor e do dialeto em que se escreve. O primeiro movimento é do professor na direção do aluno enquanto um ser capaz de um discurso que o professor quer escutar e dar a escutar, inclusive ao próprio aluno.

Escutar o que o aluno tem a dizer não significa o paternalismo que se contenta com qualquer coisa que o aluno tenha escrito, chegando à conclusão de que dá pra entender o que ele quis dizer na sua confusa fala ou no seu canhestro e desajeitado texto, avaliado como o máximo que ele pode produzir dada a sua deficiente circunstância. Significa levar o aluno a fazer-se entender, inclusive por ele mesmo, fazer-lhe as perguntas que o levem a preencher as lacunas que no seu texto representam as lacunas de seu entendimento; cobrar-lhe as informações necessárias para torná-lo inteligível, a clareza na expressão da opinião que quer apresentar, os argumentos que vão dar-lhe respeitabilidade, o encadeamento que vai capturar o leitor. É cobrar dele o esforço de garimpar - no seu dialeto ou no dialeto a que começa a ter acesso em suas leituras - os recursos expressivos necessários para dizer o que tem a dizer. Implica trabalho do professor sobre o trabalho do aluno e conduz ao trabalho do aluno sobre esse trabalho do professor, que é inquirir o que ele tem a dizer e ajudá-lo a extrair essa fala de dentro dele para torná-la clara, precisa, concisa, elegante, contundente. A leitura do professor vai concretizar para o aluno a singela mensagem de que a tarefa de apropriar-se da língua da língua em que se escreve para pô-la a serviço de suas necessidades expressivas é - ao contrário do que fica dizendo o tempo todo o discurso terrorista discriminatório das elites - possível, pessoal, necessária e intransferível.

A produção de cidadania continua na tarefa, concomitante a essa, de transformar o aluno em leitor, proporcionando-lhe acesso aos recursos expressivos construídos historicamente na língua em que se escreve para que ele se assuma como participante dessa construção e se aproprie desses recursos expressivos, pondo-os, juntamente com aqueles construídos no seu dialeto, a serviço de sua compreensão e expressão da realidade que compartilha nessa língua comum. Trata-se de promover entre a língua escrita e o dialeto do aluno um diálogo que só se torna acessível a um leitor; por isso, a aula de Português não faz sentido se não for dada para leitores. Só o leitor pode ser chamado a ler melhor o que leu e a escrever melhor o que escreveu, pois a noção de melhor, de qualidade, só pode ser construída por quem dispõe de termos de comparação ${ }^{9}$. Leitor, por isso, é necessariamente leitor de muitos e muitos textos em quantidade e de alguns textos especiais em qualidade. Cabe ao professor instalar no aluno o gosto pela leitura, transformar esse gosto em necessidade, ensinando o aluno a dimensionar o que leu pelo que vive e a enriquecer o que vive pelo que leu. $\mathrm{O}$ professor de Português não pode nem pressupor o leitor nem esperar por ele; sua tarefa é construí-lo.

\section{3 - ENSINAR PORTUGUÊS É ENSINAR A LER PARA PRODUZIR SENTIDO}

\footnotetext{
${ }^{8}$ Ver o relato de experiência de Eglê Franchi em A redação na escola; e as crianças eram difíceis, 1984. Neste livro ela trata de crianças estigmatizadas como repetentes em um colégio público de periferia urbana que recuperaram sua dignidade, escrevendo no seu dialeto e, a partir dessa experiência, começaram o seu aprendizado da língua culta para resolver problemas que só textos escritos naquela língua poderiam resolver.

${ }^{9}$ Ver especialmente o capítulo 3 de Portos de Passagem, citado acima na nota 7.
} 
A aula de Português, que trata da língua escrita, só faz sentido se for dada por um leitor para leitores, que só para leitores o estudo da língua escrita não se apresenta como um problema mas como a solução de um problema. Por isso, ao encontrar-se, na $5^{\mathrm{a}}$ série, com um aluno alfabetizado que, via de regra, além de não se ter tornado leitor, desenvolveu uma atitude negativa com relação à leitura, não cabe ao professor de Português apenas lamentar essa constatação, mas empreender a tarefa de desenvolver-lhe o gosto, o hábito e a necessidade da leitura. O mesmo vale para o professor de Português que se encontra com esse aluno na $6^{\mathrm{a}}$, na $7^{\mathrm{a}}$, na $8^{\mathrm{a}}$, no $2^{\mathrm{o}}$ grau.

O professor de Português precisa ocupar-se da formação do leitor porque, se a escola não transformar os alunos em leitores, nenhuma outra instituição da sociedade o fará, com exceção talvez de alguma família que tenha condições econômicas, culturais e materiais de acumular livros em casa e de promover um grande esforço de resistência aos filmes e desenhos animados da televisão, que suprem a necessidade de fantasia e de narrativa que as crianças da era pré-televisão eram obrigadas a saciar nos livros, nas histórias em quadrinhos e no cinema semanal. A escola, no entanto, sabendo que a realidade da esmagadora maioria das casas de seus alunos é muito diferente dessa, que o mais comum é nelas não haver sequer quem os possa ajudar nos trabalhos escolares - e muito menos livros e resistência à televisão - , a escola, se quiser trabalhar direito, não pode contar com isso ${ }^{10}$.

Leitores formam-se, para começar, com muita leitura: a leitura é também uma técnica de decodificação de sinais que precisa ser praticada para ser dominada com desenvoltura; a leitura propicia o armazenamento de informação e a composição de hierarquias em que se articulam as informações, e a quantidade de leitura também significa quantidade de informações articuladas entre si (BORDINI; AGUIAR, 1988). Limitando-se a constatar e lamentar a falta de hábito de leitura dos alunos, a escola não se tem ocupado dessa leitura de base, que precisa se dar de forma intimista e solitária para que o leitor vá construindo sua relação pessoal com o texto e descubra como ler é interessante e desenvolva o gosto pela leitura e crie a necessidade de ler e a transforme em hábito (LAJOLO, 1982).

A leitura que desenvolve a percepção da qualidade - do enredo mais bem construído, do personagem mais rico de humanidade, das situações mais complexas, do pensamento mais bem elaborado, da expressão mais clara e precisa, etc. - essa leitura tem de ser feita comparativamente, entre leituras; por isso, só leitores podem fazer leitura reflexiva. Duas são, portanto, as leituras com que tem de lidar o professor de Português: a leitura de formação de leitor e a leitura em profundidade de textos cuja leitura vale a pena aprofundar. Chegando-lhe, na $5^{a}$ série, o aluno leitor, cabe ao professor desenvolver-lhe essa leitura em profundidade $\mathrm{e}$ iniciá-lo na leitura reflexiva das obras mais relevantes da literatura brasileira.

Tentando cumprir sua tarefa de ensinar seus alunos a produzir conhecimento inserido na produção histórica do conhecimento, registrado em textos, a escola tem tentado ocupar-se da segunda leitura, dizendo aos alunos quais são os textos que eles devem ler para que se tornem autônomos em sua relação com o saber e mostrando-lhes a leitura que fez deles a tradição. Essa prática exercida com alunos que ainda não se transformaram em leitores acabou diluída na interpretação de texto, exercícios em que o aluno tem de adivinhar o que o professor acha que o autor do texto estudado quis dizer, o que tanto cassa a leitura que o aluno não chegou a fazer quanto torna estereotipada e estéril a leitura da tradição.

Não é apenas a aula de Português que só faz sentido se for dada por um leitor para leitores; qualquer disciplina pressupõe a leitura como forma de processamento pessoal e metódico, no ritmo individual da cada um, das informações e das relações com que construir o saber e com que constituir a percepção crítica, que só se forma num contato pessoal refletido

${ }^{10}$ Ver a pesquisa de Lilian Lopes M. da Silva, mostrando que a criança (não) lê porque a escola (não) mandou; enfim, a escola é a única responsável pelo que lê o aluno e pelo que o aluno deixou de ler. A pesquisa está no seu livro A escolarização do leitor, 1986. 
com posições confrontantes. Por isso, o professor de Português não vai de forma genérica ensinar a ler, não será o professor de interpretação de texto. A tentativa de atribuir-lhe a tarefa de fornecer os instrumentos para que os alunos consigam compreender textos de História, de Ciências, do que seja, baseia-se no equívoco de que ler é apenas uma técnica de decodificação do texto, na errônea presunção de que todo o sentido do texto está contido nas palavras e frases que o compõem, negligenciando o conjunto de informações prévias, os sentidos paroquiais das expressões no contexto de cada disciplina e desconsiderando que as palavras não têm sempre os mesmos sentidos, que eles variam de acordo com o tema geral a que está vinculado o texto que elas compõem.

Leitores formam-se, pois, com uma melhor leitura, que a leitura não é apenas uma técnica de decodificação: é produção de sentido. Ler é atribuir significado a um texto, relacionando-o a outros textos lidos, tentando reconhecer o significado que o seu autor quis construir e decidir se algum outro significado contido no texto é ou não mais significativo do que aquele ${ }^{11}$. Relacionar o texto lido a outros textos implica não só um repertório de textos com que estabelecer tal relação, mas também um conjunto de critérios que selecione entre os textos lidos aqueles que são significativos para tal relação. Tais critérios não são apenas construções espontâneas de cada leitor; são, principalmente, produtos do exercício da leitura reflexiva conduzida pelo professor da disciplina a que se refere o texto (o que não quer dizer que a leitura em profundidade conduzida pelo professor de Ciências, por exemplo, não vá se refletir na qualidade da leitura de uma obra literária ou de um texto sobre história: a leitura é irremediavelmente interdisciplinar).

Isto quer dizer que cada leitor produz, para o texto que lê, o sentido que pode, em função da quantidade e da qualidade de sua leitura, isto é, em função de tudo o que já leu e do trabalho que estiver disposto a dedicar ao estabelecimento das relações que determinou como significativas de serem estabelecidas entre os textos lidos e o texto que lê. Ler em profundidade, ler reflexivamente, ao ponto de deliberar se vai acatar o sentido pretendido pela autor, ou se vai propor outro sentido só é dado a quem se qualifica como leitor.

Ler em profundidade é reler: o tipo de aprendizado conduzido pela leitura é o da apropriação individual do conhecimento, da reflexão a respeito do que lê. A releitura proporciona um refletido confronto, no ritmo individual de cada leitor, entre o que está sendo lido, o já lido e o vivido, possibilitando ao leitor reconhecer em si o que o texto diz, identificar em seus sentimentos os sentimentos nele configurados, encontrar-se com a expressão adequada para uma idéia até então vagamente concebida e com razões que apóiem alguma convicção ainda não muito forte ou chocar-se com argumentos que abalam alguma forte convicção.

Ensinar a ler, tarefa do professor - de Português, de Ciências, de Geografia, de História, de Matemática, de Artes, de... - é promover um encontro de leituras: a do aluno produz um sentido; a do professor produz outro, e ambas são indispensáveis para que se dê o diálogo pedagógico, que não se dá, no entanto, apenas entre a leitura do aluno e a do professor, pois a elas cabe ao professor agregar a leitura feita pela tradição não como um corpo estranho ao diálogo, para substituir-se às duas outras: o professor já elaborou sua leitura num diálogo com a leitura da tradição, o que não quer dizer que tenha aderido a ela, até porque a leitura da tradição não é unívoca, pois que se constituiu também de diálogos de leituras. O professor traz a leitura da tradição para iluminar a leitura individual do aluno, para pôr à sua disposição critérios com que avaliar a significação do que lê.

$\mathrm{Na}$ aula de Português, a finalidade da leitura é o aprimoramento da capacidade de ler em profundidade para dar suporte à atividade de produção de texto e para possibilitar a discussão em profundidade de um elenco de obras fundamentais da literatura brasileira; as outras atividades de leitura são meios que encaminham esse fim. O professor não vai interferir na leitura que o aluno realizou de qualquer dos livros componentes daquele acervo de leituras

${ }^{11}$ Ver o texto de Maurizzio Gnerre citado acima na nota 2 e, na mesma obra, "Considerações sobre o campo de estudo da escrita", p. 25-80. 
básicas; vai interferir na leitura que o aluno realiza dos livros que compõem essa leitura formativa, não, evidentemente, para desqualificá-la, nem para anulá-la, nem para substituí-la por outra. Vai tomar como ponto de partida a leitura do aluno, ouvi-la com atenção, para confrontá-la com a própria leitura e com a leitura da tradição. De que modo se reconhece o professor no que leu e o que foi capaz de aprender no que leu, essa é a lição que ele precisa ensinar no concreto processamento de cada texto lido com seu aluno ao organizar o confronto das leituras dos alunos, da sua leitura e da leitura da tradição.

\section{4 - ENSINAR PORTUGUÊS É ENSINAR A ESCREVER}

A escrita nunca foi a escrita da fala: constituiu-se sempre dentro de um processo de legitimação de formas lingüísticas de um dos dialetos falados por um grupo de uma determinada sociedade como um dos resultados da luta política entre grupos sociais que falavam diferentes dialetos. $\mathrm{O}$ dialeto dos vencedores foi elevado, por causa do poder político conquistado por seus falantes, à condição de melhor forma de falar a língua comum a essa sociedade. A escrita representou a legitimação tanto daquele dialeto quanto da tradição cultural a que se vinculavam os conteúdos a serem expressos na escrita. A língua culta ou padrão é um sistema comunicativo fixado nessa escrita e geralmente é considerada como a verdadeira, a correta, a única língua capaz de expressar aqueles conteúdos ${ }^{12}$.

Isso quer dizer que há dialetos que não têm expressão escrita - como, por exemplo, os dialetos populares do Brasil - e que há conteúdos inexpressados pela língua culta - como por exemplo, a vida dos alunos das classes populares, a dos trabalhadores sem terra, a dos índios. Há, no entanto, dialetos que têm expressão escrita, como, por exemplo, o dialeto que falam os habitantes da região de Roma, na Itália, que, como demonstrou Miriam Lemle (1983), diferencia-se da língua culta italiana, em aspectos muito semelhantes aos que distinguem o dialeto popular carioca da língua portuguesa culta. Há literatura - poesia, romance, contos nesse dialeto. E em outros dialetos dentro da Itália.

No Brasil, no entanto, até mesmo a existência de dialetos foi negada durante muito tempo pela ciência oficial, que sempre falou na extraordinária homogeneidade de nossa língua, ou seja, ficava implícito nessa formulação que não falamos dialeto nenhum; todos falamos muito mal - e só por incompetência da raça - a única língua em que deveríamos ter aprendido a falar desde criancinhas. Diferentemente do que acontece nas escolas italianas, onde as crianças que falam romanesco, sardo, vêneto, etc. aprendem o toscano, o dialeto que foi elevado à condição de língua oficial e fixado na escrita, no Brasil, a escola desobrigou-se de ensinar a língua portuguesa culta às criancinhas que não aprenderam a língua portuguesa culta em casa, mas que em casa aprenderam a falar um dialeto que a escola - a sociedade - não reconhece como tal; a consequiência é que essas crianças acabam escorraçadas não só da escola e da língua culta que a escola se recusou a ensinar, mas também da própria linguagem, que a escola indevidamente confunde com a língua portuguesa culta. A escola, que deveria proporcionar o acesso dessas crianças à língua escrita, acaba por nos alijar a todos até mesmo da nossa língua falada, impedindo-nos não só de escrevermos mas também falarmos de nós mesmos, de contarmos nossas história e de construirmos uma auto-estima e uma reflexão a respeito de nós mesmos, já que não nos sobrou língua nenhuma (SOARES, 1986).

E a literatura brasileira? A ciência oficial também não poupou esforços para nos convencer de que literatura é só literatura e nada tem a ver nem com a vida comum nem com a língua comum: literatura é coisa de artistas, de gente diferente, que tem licença poética para escrever de uma forma criativa, que não é acessível às pessoas comuns e que nada tem a ver com a língua que todos deveriam falar.

\footnotetext{
${ }^{12}$ Ver, a propósito da questão dialetal, o livro de Magda Soares, Linguagem e Escola; uma perspectiva social, 1986.
} 
Portanto, se quisermos, em nossa Escola Cidadã, ensinar nossos alunos a ler e a escrever para dominarem a língua escrita sem renegarem o seu dialeto, tomando a palavra para organizarem seu entendimento pessoal sobre o mundo em que vivem, tal como fez a literatura brasileira, cujo processo de desvelamento da nossa realidade social tomaremos como guia para a nossa tarefa pedagógica. Se quisermos dar nossa contribuição para a construção da cidadania, teremos de desmentir tudo isso. Estamos preparados para enfrentar a ciência oficial? Sabemos todos que não.

Então, o professor de Português que tomar a decisão política de inserir-se e inserir seu aluno neste projeto precisa assumir, a partir da precariedade de sua formação, a sua leitura, a sua escrita e a sua percepção da língua em que fala e em que escreve. Precisa atrever-se a olhar para o que vê com seus próprios olhos e a falar e escrever sobre o que viu no seu dialeto, nele buscando os recursos expressivos com que configurar a percepção de sua realidade pessoal e social, como se estivesse conferindo pela primeira vez à língua que fala a dignidade de língua escrita para levar bem longe uma proposta de diálogo a respeito dessa particular percepção, como fizeram Simões Lopes Neto e Guimarães Rosa, que puseram por escrito a palavra que devolveram ao velho gaúcho e ao velho sertanejo para que nos ensinassem a respeito deles e de nós mesmos. Precisa, em seguida, esse professor de Português, atrever-se a lançar mão dos recursos expressivos da língua que não fala, pondo a serviço de sua percepção da realidade a língua constituída pela tradição escrita em Português, tomando-a como um bem comum à disposição de todos e recusando-se à intimidação privatista que postula um correto uso estabelecido de uma vez por todas para cada expressão, usando-as, tal como fez Euclides da Cunha, para mais clara e precisamente nos contar o que viu em sua tentativa de olhar de perto o que foi ver com seus próprios olhos.

Precisa atrever-se a ler com a precariedade de sua leitura, dar ao texto lido, em primeiro lugar, a própria interpretação, sem permitir que ela seja atropelada pela interpretação correta do manual ou da crítica especializada ou de quem quer que seja. Precisa começar por permitirse gostar ou não gostar, tentando entender por que gostou ou não gostou antes de querer saber por que, ao texto em questão, a tradição atribui tal ou tal valor.

Precisa atrever-se a exercitar suas reflexões intuitivas sobre a língua para trabalhar a qualidade de sua leitura, de seus textos e de suas falas. É também do confronto entre essas reflexões intuitivas com as elaborações dos cientistas a que tem acesso que o professor de Português vai construir o discernimento para selecionar, dentre as reflexões que os cientistas põem à sua disposição, aquelas que vêm ao caso para o seu uso de leitor e de escritor e para o seu trabalho em sala de aula. A escuta do que o aluno diz e a leitura de seu texto com a intenção de querer entender o que ele quer mesmo dizer, que implica respeito pelo seu saber lingüístico, vai implicar um anterior respeito pelo próprio saber lingüístico, pela própria capacidade de assumir a palavra para propor a seu aluno o diálogo da palavra que ele deve assumir com a palavra assumida pela literatura brasileira.

A literatura brasileira que o professor de Português vai ensinar seu aluno a ler e escrever não será a manifestação de uma individualidade diferenciada por um imponderável talento ou uma intransferível criatividade, mas o esforço histórico que construiu uma cultura de resistência ao colonialismo, como um conjunto de personagens que nos representam, que enfrentam conflitos em que nos reconhecemos e que nos ensinam a respeito de nós mesmos e dos conflitos que enfrentamos, como um universo de sentimentos, sensações, categorias com que organizamos nossa percepção da vida que vivemos, construído pelo olhar de romancistas, poetas, ensaístas que forçaram seus olhos a perfurar a carapaça de conceitos construídos a nosso respeito pelo discurso da elite predatória que nos domina, um discurso colonialista e colonizado que nos vem estigmatizando como fenômenos incompletos e degradados de alguma civilização central em moda.

Escrever literatura brasileira será, portanto, o exercício da percepção de nossa realidade social e pessoal de brasileiros com a finalidade com que sempre escreveu a literatura brasileira - 
dar-nos a conhecer a nós mesmos -, enfrentando a mesma dificuldade que sempre enfrentou a literatura brasileira - trabalhar uma língua mais preparada para expressar a percepção colonizada do que a autônoma -, isto é, ensinar a escrever a partir do pressuposto de que fazem parte do processo de pensar o Brasil - o trabalho de descobrir o Brasil e o de armar a língua contra a percepção colonizada que a configura, seja no texto informativo, seja no texto que se quer artístico ou mesmo no que se pretende científico. Quem nos ensinou a questionar a percepção colonizada foi a literatura tentando olhar perto para as coisas e para as palavras. Foi, por exemplo, a ciência de Os Sertões, cujas palavras, selecionadas pela precisão com que conseguiriam expressar o que o olho se esforçava por examinar o mais de perto possível, acabaram por negar os pressupostos com que se armara esse olho para examinar as coisas que fora ver e, por causa disso, acabaram por construir novos pressupostos com que enxergá-las.

Desse modo, a tarefa a ser desenvolvido na aula de Português de uma escola que quer construir a cidadania é levar os alunos a contar a história de suas vidas, de suas famílias, de sua comunidade, falando de sua realidade interior e de sua realidade social mais próxima para que produzam conhecimento a respeito deles mesmo e de seus leitores - o professor, os colegas de aula, os demais alunos da escola, os demais professores, os pais, a comunidade escolar, o bairro, a cidade, de acordo com o programa de publicação que a escola conseguir implementar.

O professor de Português que vai realizar esta tarefa terá coração livre do temor de vitimar-se com o tacape que foi obrigado a manter sobre a cabeça de seus aterrorizados alunos: sua maior qualidade não será mais a capacidade de decorar os nomes que a gramática dá aos fatos que seleciona como ensináveis, nem a de conhecer as picuinhas da norma culta, mas sua disposição de exercitar a sua habilidade artesanal de escrever na língua que vai ensinar ao seu aluno, a língua da resistência à diluição colonizada e da produção de conhecimento a respeito de nós mesmos.

Isso quer dizer também que a aula de Português tem um conteúdo e que o professor de Português não é genericamente - a não ser no sentido em que todos os demais o são - o professor de ler e escrever. Ensinar a ler e escrever é a tarefa de todo professor, pois ensinar é proporcionar condições para que o aluno se torne capaz de expressar-se na linguagem própria da ciência ou da arte que com ele processa em sua sala de aula. Nesse sentido, ensinar a ler e escrever Ciências é a tarefa do professor de Ciências; ensinar a ler e escrever Geografia é a tarefa do professor de Geografia; ensinar a ler e escrever História é tarefa do professor de História e assim por diante.

Portanto, todos nós, professores, é que vamos, juntamente com nossos alunos, aprender a escrever nossas palavras, trazendo para dentro da língua escrita a expressão de quem se esforça para enxergar bem de perto o modo como vemos nosso jeito de levar a vida, como entendemos as relações dentro de nossa comunidade, como percebemos o lugar que ocupamos dentro da sociedade, como consideramos o apreço em que nos têm os poderosos, como percebemos o que futuro nos reserva, que sonhos nos permitimos acalentar.

\section{BIBLIOGRAFIA}

BORDINI, Maria da Glória; AGUIAR, Vera Teixeira de. Literatura: a formação do leitor. Porto Alegre, Mercado Aberto, 1988.

BOSI, Alfredo. Entrevista a Flavio Aguiar . Brasil Agora, v. 2, n. 35, p.12.

FRANCHI, Eglê. A redação na escola. São Paulo, Martins Fontes, 1984.

GERALDI, João Wanderley. Portos de Passagem. São Paulo, Martins Fontes, 1991. 
GNERRE, Maurizzio. Linguagem, escrita e poder. São Paulo, Martins Fontes, 1985.

LAJOLO, Marisa. Usos e abusos da literatura na escola. Porto Alegre, Globo, 1982.

LEMLE, Miriam. A variação na forma fonológica. Boletim da ABRALIN, São Paulo, v. 8, n. 1, p. 22-29, set. 1983.

LUFT, Celso Pedro. Língua e liberdade. 3 ed. Porto Alegre, LPM, 1985.

POSSENTI, Sírio. Discurso, estilo e subjetividade. São Paulo, Martins Fontes, 1988.

RIBEIRO, Darcy. Sobre o Óbvio. In: Ensaios Insólitos. Porto Alegre, LPM. 1979.

SECRETARIA MUNICIPAL DE EDUCAÇÃO. Princípios de Convivência. Cadernos pedagógicos, Porto Alegre, v. 4, n. 1, p.19, abr. 1995.

SILVA, Lilian Lopes Martin da. A escolarização do leitor. Porto Alegre, Mercado Aberto, 1986.

SOARES, Magda. Linguagem e escola. São Paulo, Ática, 1986. 